\title{
Implementation of Problem-Based Learning (PBL) in Gender and Agribusiness Development Course and Its Impact on Students' Learning Process
}

\author{
Yuerlita $^{1, *}$ Rudi Febriamansyah ${ }^{1}$ Vonny Indah Mutiara $^{1}$
}

\author{
${ }^{1}$ Department of Socio-economics, Faculty of Agriculture, Universitas Andalas, Limau Manis, Padang, West Sumatera, \\ Indonesia. \\ *Corresponding author. Email: yuerlita@agr.unand.ac.id
}

\begin{abstract}
Problem-based learning (PBL) is one of the widely implemented active learning method. This study aims to describe implementation of PBL, analyse the effect of PBL in teaching and learning and describe students' satisfaction in gender and agribusiness development course, undergraduate level. This study used both quantitative and qualitative approach with descriptive design. The instrument consists of a set of questionnaires and semi-structured interviews. The survey was conducted to 20 undergraduates students who took gender and agribusiness development class. Interview sessions were carried on selected respondents. Quantitative data were analysed using descriptive statistics. The results show that most of students were able to present solution of the given problems through group activities, self- learning, lecturer guidance and independent learning. The findings also show PBL could enhance students' hard skill and soft skills. students' motivation, communication skills, and independent learning are generated through PBL. Students also positively perceived on the implementation of PBL in gender and agribusiness development learning process. PBL is a teaching strategy that needs to be applied in the process of learning in higher institutions in order to achieve learning outcomes and develop students' critical thinking and skills.
\end{abstract}

Keywords: Problem-based learning, higher education, critical thinking, communication skills, Agribusiness

\section{INTRODUCTION}

In the past few years, there has been a general transition in higher education learning approach into student-centered learning model. Student-centered learning model emphasize on self-directed learning and collaborative learning to develop critical thinking and students' skills. Problem-based learning (PBL) is one example of among various innovative learning approach.

PBL was previously introduced in1969 at McMaster University Canada in the field of medicine. Since then PBL has been magnificently used not only by other medical program but also other field including economics, laws, psychology and engineering. PBL is an active learning strategy enable students to work collaboratively and provide more opportunity for students to learn through their own direction [1]. Thus, PBL enable students to be the center of their learning process and responsible for that process as well.

Within its raising practice and acceptance of PBL, there has been also an increasing number of studies examining various aspects of PBL such as studies on the process of PBL[2], [3], effectiveness of PBL [4]-[6]. PBL has potential to advance reaching and learning process particularly in higher education. However, the questions remain on how the implementation strategy of PBL, how it has impacted in teaching and learning process and how is students' satisfaction on the PBL method. This study aims to answer those questions with the following objectives:

1. To describe the implementation of problem-based learning in teaching and learning process in Gender and Agribusiness Development Course

2. To analyze the effect of the implementation of problembased learning in teaching and learning process in Gender and Agribusiness Development Course

3. To analyze level of students' satisfaction towards the implementation of problem based-learning in teaching and learning process 


\subsection{Problem-based learning in higher education institution}

Problem-based learning (PBL) has been widely implemented in various fields and educational level in order to expand students' critical thinking and develop problem- solving skill through factual learning situation. PBL has positively contribute to students learning process and outcomes as it integrates theory and practice with collaborative and self-directed learning that enhances students' motivation to learn [7]. In addition, PBL is considered more effective than teacher-centered learning to stimulate long-term retention of knowledge and skills [4]. It indicates that consistency in applying studentcentered learning approach, such as PBL is highly required so that students are involved in the active learning that shape their knowledge and skills through the whole learning process.

\subsection{The importance of PBL to achieve learning outcomes}

Studies on the effect of PBL to the achievement of learning outcomes and students ability from various aspect has been widely examined. A study about the impact of PBL on critical thinking and student learning outcomes found that implementation of PBL has improve critical thinking and learning outcomes of the students [8]. Also, PBL has improved students' academic achievement and their creativity, develop students' critical thinking [9], [10]. On the other hands, in some cases students struggling in PBL learning process, students perceive that they have insufficient time for discussion, understanding and complete the PBL tasks [11]. It depicts that there is a need to improve the process based on the issues and problem faced during its implementation from variety of perspectives supported by curriculum elements.

\section{METHODS}

This study is a descriptive design by using both qualitative and quantitative approach. The implementation of PBL was descriptively explained. A survey was conducted to analyse the effect of PBL and students' satisfaction towards implementation of PBL. All students who have taken gender and agribusiness development course was interviewed with total number of 20 respondents. The data were obtained using questionnaires and interview guide. A set of questionnaire with 38 items or questions with five point Likert Scale was used to collect data on PBL strategy implementation, effect and level of students' satisfaction. The data were analysed using Statistical Package for Social Science (SPSS 17) to obtain weighted average index of each item.

\section{RESULTS AND DISCUSSION}

\subsection{Problem-based learning implementation strategy}

Implementation of PBL in gender and agribusiness development course involves in four main stages:

1. Class meeting I: Definition of the problem, during this stage lecturer presents a real problem that require solutions. The problem should be able to initiate productive discussion among the group members and among the group in the class. The students start discussing the problem by defining the problem and identify the learning topics or information to be searched and assigned to each group member. In this stage, lecturer or tutor can also involve by delivering reflective questions to the students.

The PBL phases that contribute to students' learning process as described by PBL literatures are PBL that begin with problem analysis then continue with self-directed learning and some stages of reporting (10). The process of PBL is an important factor that determine the success of PBL implementation. Generally, PBL cover three main phases involving directed learning process and collaborative process. All phases in PBL strongly influenced each other, previous phase influence next phase and it is a cumulative phase (11). On the other hands, effective PBL is mainly determined by students' engagement with the problem, while the collaborative component did not significantly contribute to students learning (12). PBL is considered as an effective teaching and learning approach, specifically for long-term knowledge and applications.

2. Class meeting II: Diagnosis of the problem. After the group members study independently, they meet in the second meeting to report their exploration about the topics or information related to the problem. Students discuss within their group to understand the information collected by all members and outline the information that have been clearly explain and those are still missing to construct solution of the problem.

3. Class meeting III: students continue their discussion to integrate knowledge in order to set solution of the problem, review alternative solution and finalize group report.

4. Class meeting IV: each of the group presents their report, evaluate other group presentation, discussion to define the best solution of the problem. Although the groups may present different solutions, the exchange of information and experience can help them to have better understanding of the problem and figure out the best solution. At this stage lecturer or tutor is responsible for facilitating the session, giving comments and questions to the group and giving 
some more explanation if needed.

The cycles of implemented PBL approach in gender and agribusiness development course can be defined as: problem/project - group discussion - self-learning- group discussion - making the group report - presentation in class - review.

Students were asked about the implementation strategy and their involvement in PBL class. The results are described in table 1.

Table 1. Strategy implementation of PBL in Gender and Agribusiness development course

\begin{tabular}{llllllll}
\hline No & $\begin{array}{l}\text { How often you have been doing the following activities in } \\
\text { PBL class (gender and agribusiness development course) }\end{array}$ & $\mathbf{1}$ & $\mathbf{2}$ & $\mathbf{3}$ & $\mathbf{4}$ & $\mathbf{5}$ & Mean \\
\hline 1. & Attend lectures & 0 & 0 & 1 & 8 & 11 & 4.5 \\
2. & Find resources online or from library to solve problem in PBL & 0 & 0 & 7 & 10 & 3 & 3.8 \\
3. & Work in PBL group supervised/unsupervised by lecturer/tutor & 0 & 1 & 3 & 10 & 6 & 4.05 \\
4. & Write PBL individual reports & 0 & 1 & 0 & 5 & 14 & 4.6 \\
5. & Write PBL group reports & 0 & 0 & 0 & 4 & 16 & 4.8 \\
6. & Give presentation & 0 & 1 & 8 & 9 & 2 & 3.6 \\
7. & Actively involved in group discussion & 0 & 1 & 5 & 9 & 5 & 3.9 \\
8. & Actively involved in class discussion & 0 & 2 & 13 & 5 & 0 & 3.15 \\
9. & Actively involved in gaining knowledge about gender & 0 & 1 & 5 & 11 & 2 \\
\hline
\end{tabular}

(1=never, 2 =rare, $3=$ sometimes, 4=often, 5=always)

PBL sessions were dominated by lecture sessions (mean $=4.5)$ and group work (4.05), also students' contribution in individual (mean $=4.6)$ and group reports (mean $=4.8)$. Lecture sessions implemented to provide a brief guide of the problem presented and the concepts to be learned by students. However, lecture sessions were no longer dominated by lecturer, instead lecture activities became the medium for lecturers and students exchange ideas, and sharing to submit problems to be solved in group activities. Students attendance in lecture series become an important issue to make sure that students are able participate in all PBL sessions (both self-learning and collaborative learning).

\subsection{The effect of applying problem-based learning among Gender and Agribusiness Development Students}

The effect of PBL implementation in gender and agribusiness development class has been analyzed emphasizing on motivation, self-learning, collaborative and communication skills. The results presented in table 2 .

Table 2. Effect of PBL on students, motivation, self-learning, and communication skill.

\begin{tabular}{|c|c|c|c|c|c|c|c|}
\hline No & Motivation in PBL class & 1 & 2 & 3 & 4 & 5 & Mean \\
\hline 1. & I am studying with full of interest during PBL class. & 0 & 0 & 8 & 7 & 5 & 3.85 \\
\hline \multirow[t]{2}{*}{2.} & $\begin{array}{l}\text { I enjoy learning gender and development subject } \\
\text { because of the use of PBL approach. }\end{array}$ & 0 & 1 & 5 & 8 & 6 & 3.95 \\
\hline & Self-directed learning in PBL class & 1 & 2 & 3 & 4 & 5 & \\
\hline 1. & I learn a lot by reading books in PBL class. & 0 & 2 & 7 & 10 & 1 & 3.5 \\
\hline 2. & I am finding information in the library during PBL. & 0 & 4 & 14 & 2 & 0 & 2.9 \\
\hline 3. & I am finding information on the internet during PBL. & 0 & 1 & 3 & 10 & 6 & 4.05 \\
\hline 4. & I manage my time effectively during PBL. & 0 & 2 & 8 & 8 & 2 & 3.5 \\
\hline 5. & $\begin{array}{l}\text { I can identify my learning goals without depending on my } \\
\text { lecturer/tutor during PBL. }\end{array}$ & 0 & 1 & 12 & 5 & 2 & 3.4 \\
\hline 6. & I take responsibility for my own learning during PBL. & 0 & 1 & 7 & 9 & 3 & 3.7 \\
\hline
\end{tabular}




\begin{tabular}{llllllll}
\hline & Communication skills in PBL class & $\mathbf{1}$ & $\mathbf{2}$ & $\mathbf{3}$ & $\mathbf{4}$ & $\mathbf{5}$ & \\
\hline 1. & I am good at writing reports/ essays in PBL class. & 0 & 1 & 1 & 13 & 5 & 4.1 \\
2. & I speak well in front of a group in PBL class. & 0 & 2 & 5 & 10 & 3 & 3.7 \\
\hline
\end{tabular}

(1=totally not agree, $2=$ not agree, $3=$ neutral, $4=$ agree, $5=$ strongly agree)

Majority of students were motivated to learn gender and development through PBL. Improve independent learning skills, majority of students can search online sources and information individually, students prefer online information than library --- self-learning is

\subsection{Students' perception on the implementation of problem-based learning in Gender dan Agribusiness Development course}

Table 3. The level of students' satisfaction in PBL learning process

\begin{tabular}{|c|c|c|c|c|c|c|c|}
\hline $\begin{array}{l}\mathbf{N} \\
\mathbf{o}\end{array}$ & $\begin{array}{l}\text { How often you have been doing the following activities in } \\
\text { PBL class (gender and agribusiness development course) }\end{array}$ & 1 & 2 & 3 & 4 & 5 & Mean \\
\hline 1. & I learned more in PBL compared to conventional lecture & 0 & 1 & 8 & 7 & 4 & 3.7 \\
\hline 2. & I recommend PBL in other subjects & 0 & 2 & 8 & 6 & 4 & 3.6 \\
\hline 3. & I like tackling unfamiliar problems in PBL & 0 & 1 & 8 & 8 & 3 & 3.65 \\
\hline 4. & $\begin{array}{l}\text { In PBL, I have developed many useful strategies to help me } \\
\text { in my learning }\end{array}$ & 0 & 1 & 11 & 7 & 1 & 3.4 \\
\hline 5. & $\begin{array}{l}\text { Lecturers give me regular feedback during PBL on how I am } \\
\text { doing with my project }\end{array}$ & 0 & 0 & 5 & 10 & 5 & 4 \\
\hline 6. & $\begin{array}{l}\text { I am able to get help from my lecturer whenever I need it } \\
\text { during PBL }\end{array}$ & 0 & 0 & 5 & 12 & 3 & 3.9 \\
\hline 7. & PBL learning environment helps shaping my critical thinking & 0 & 1 & 4 & 10 & 5 & 3.95 \\
\hline 8. & Learning process becomes more effective in PBL & 0 & 1 & 11 & 5 & 3 & 3.5 \\
\hline 9. & My hard skill and soft skill is improving through PBL & 0 & 0 & 10 & 7 & 3 & 3.65 \\
\hline
\end{tabular}

(1=totally not agree, 2 =not agree, $3=$ neutral, $4=$ agree, $5=$ strongly agree)

The results show that students agreed that PBL stimulates them to learn more and are able to find information by themselves compare to conventional lecture method (teacher-centered learning). They also agreed to recommend PBL for other subjects. This finding in line with some other studies that found students have positive perception towards implementation of PBL in learning process as it enhance students motivation, collaboration and independent learning, critical thinking and communication skills [9]-[11], [13], [14]. Although in some other studies found that students require more time to get acquainted with PBL learning process [15]. Improvement in the implementation process of PBL is always possible to do ascertain PBL learning environment for students. Thus, they are able to experience new learning skills and get benefits from the learning process. important aspect to achieve quality learning [12]. Combination of self-learning and collaborative learning enable students build their communication skills, they have to share ideas and discuss among the group members and other group.

The study discusses the level of students' satisfaction in the implementation of PBL in gender and agribusiness development course. The results presented in table 3 . 


\section{ACKNOWLEDGMENT}

This work was supported by Lembaga Pengembangan Pendidikan dan Penjaminan Mutu (LP3M) or institution for educational development and quality assurance (LP3M), Universitas Andalas.

\section{REFERENCES}

[1] J. Strobel and A. van Barneveld, "When is PBL More Effective? A Meta-synthesis of Meta- analyses Comparing PBL to Conventional Classrooms," Interdiscip. J. Probl. Learn., vol. 3, no. 1, 2009, doi: 10.7771/1541-5015.1046.

[2] E. H. J. Yew and K. Goh, "Problem-Based Learning: An Overview of its Process and Impact on Learning," Heal. Prof. Educ., vol. 2, no. 2, pp. 75-79, 2016, doi: 10.1016/j.hpe.2016.01.004.

[3] S. Amin, "Pengaruh Model Pembelajaran Problem Based Learning Terhadap Kemampuan Berpikir Kritis Dan Hasil Belajar Geografi," J. Pendidik. Geogr., vol. 4, no. 3, pp. 25-36, 2017.

[4] E. H. J. Yew, E. Chng, and H. G. Schmidt, "Is learning in problem-based learning cumulative?," Adv. Heal. Sci. Educ., vol. 16, no. 4, pp. 449-464, 2011, doi: 10.1007/s10459- 010-9267-y.

[5] M. A. Pease and D. Kuhn, "Experimental analysis of the effective components of problem-based learning," Sci. Educ., vol. 95, no. 1, pp. 57-86, 2011, doi: 10.1002/sce. 20412.

[6] M. R. O. Silva and P. F. M. Lopes, "Each fisherman is different: Taking the environmental perception of small-scale fishermen into account to manage marine protected areas," Mar. Policy, vol. 51, no. 0, pp. 347-355, 2015, doi: http://dx.doi.org/10.1016/j.marpol.2014.09.019.

[7] M. C. E. Gwee, "Problem-based learning: A strategic learning system design for the education of healthcare professionals in the 21 st century," Kaohsiung J. Med. Sci., vol. 25, no. 5, pp. 231-239, 2009, doi: 10.1016/S1607- 551X(09)70067-1.

[8] A. J. S. F. Visschers-Pleijers, D. H. J. M. Dolmans, I. H. A. P. Wolfhagen, and C. P.

M. van der Vleuten, "Exploration of a method to analyze group interactions in problem-based learning," Med. Teach., vol. 26, no. 5, pp. 471-478, Aug. 2004, doi: 10.1080/01421590410001679064.

[9] A. Widowati and A. L. Belakang, "Pengembangan Critical Thinking Melalui Penerapan Model Pbl (Problem Based Learning) Dalam Pembelajaran Sains," Maj. Ilm. Pembelajaran, vol. 6, no. 1, pp. 8489, 2010.
[10] W. Wahyu, Kurnia, and R. S. Syaadah, "Implementation of problem-based learning (PBL) approach to improve student's academic achievement and creativity on the topic of electrolyte and nonelectrolyte solutions at vocational school," J. Phys. Conf. Ser., vol. 1013, no. 1, 2018, doi: 10.1088/17426596/1013/1/012096.

[11] C. E. Hmelo-Silver and H. S. Barrows, "Facilitating collaborative knowledge building," Cogn. Instr., vol. 26, no. 1, pp. 48- 94, 2008, doi: $10.1080 / 07370000701798495$.

[12] B. Zimmerman and D. Schunk, "Self-regulated learning and academic achievement: Theory," vol. 2, Jan. 2001.

[13] J. Surif, H. Ibrahim, and M. Mokhtar, "Implementation of Problem Based Learning in Higher Education Institutions and Its Impact on Students' Learning," 4th Int. Symp. Probl. Learn. 2013, pp. 66-71, 2013.

[14] N. Chadziqoh, "The Implementation of Problem Based Learning Model in Developing Students' Higher Order Thinking in Social Studies Learning (A Descriptive Study on Teacher in SMP Negeri 40 Bandung)," Int. J. Pedagog. Soc. Stud., vol. 2, no. 2, p. 72, 2018, doi: 10.17509/ijposs.v2i2.10170.

[15] S. M. Borhan, Termizi M; Yassin, "Implementation of Problem Based Learning (PBL) in a Malaysian Teacher Education Course: Issues and Benefits from Students Perspective," in PBL Across Cultures: The 4th Symposium on Problem-Based Learning (IRSPBL), 2013, pp. 181-19 